\title{
Analisis Peran Baznas Dalam Melindungi Kelompok Rentan Dan Mengurangi Kesenjangan (Studi Kasus Baznas Kabupaten Mojokerto)
}

\author{
Shinta Lintang Nurillah ${ }^{1 *}$, Ach. Yasin ${ }^{2)}$ \\ ${ }^{1,2}$ Fakultas Ekonomika dan Bisnis, Universitas Negeri Surabaya \\ *Email korespondensi: lintangshinta17@gmail.com
}

\begin{abstract}
Inequality is one of the problems in Indonesia that cannot be immediately resolved. This condition is exacerbated by the lifestyle of the people who tend to be consumerism, control of the economic sector which is only centered on a group of people and the limitations of the state in realizing its obligations as mandated in the 1945 Constitution. So an institution is needed to help accelerate government programs in alleviating vulnerable groups through programs such as empowerment. and economic assistance. The approach used in this research is descriptive qualitative with a case study method at the National Zakat Agency (BAZNAS) in Mojokerto Regency. How to collect data using interviews, observation, and documentation. Based on this research, it was found that in protecting Vulnerable Groups the efforts made by BAZNAS Mojokerto Regency have so far been good, proven by the criteria for receiving BAZNAS assistance such as KKM, Mustahiq Consumptive, Mustahiq Criterion B, Mustahiq Criterion A. Meanwhile, in reducing gaps in the region Mojokerto BAZNAS Regency cannot be said to be able to reduce the current gap.
\end{abstract}

Keyword : Role of BAZNAS, Vulnerable Groups, Gap

\section{PENDAHULUAN}

Indonesia memiliki luas daratan sebesar 1,92 juta $\mathrm{km}^{2}$ dengan persebaran penduduk $56,10 \%$ Pulau Jawa, 21,68\% Pulau Sumatera, 7,36\% Pulau Sulawesi, 6,15\% Pulau Kalimantan, 5,54\% Pulau Bali, Nusa Tenggara, sisanya 3,17\% Pulau Maluku dan Papua. Dapat dilihat distribusi penduduk di Indonesia masih terpusat di Pulau Jawa sebesar 151,59 juta jiwa (Badan Pusat Statistik, 2020). Sementara itu, dari data laju pertumbuhan penduduk di Indonesia hingga periode September 2020 jumlah penduduk di Indonesia terhitung sebesar 270,20 juta jiwa, jika dilihat dalam waktu 10 tahun terakhir dari 2010 hingga 2020 artinya terdapat peningkatan penduduk sebanyak 32,56 juta jiwa (Badan Pusat Statistik, 2020). Pertumbuhan penduduk dengan pertumbuhan ekonomi merupakan kesatuan yang tidak dapat dipisahkan, diantara keduanya harus ada keseimbangan (Rochaida, 2016). Dampak dari meningkatnya jumlah penduduk yang tidak diimbangi dengan meningkatnya pemanfaatan potensi ekonomi tidak akan berdampak baik untuk pertumbuhan ekonomi (Waluyo, 2004)
Pertumbuhan ekonomi yang tidak baik akan memunculkan masalah ekonomi seperti kemiskinan. Menurut (Badan Pusat Statistik, 2020) permasalahan kemiskinan merupakan suatu bentuk ketidaksiapan secara ekonomi dalam memenuhi kebutuhan yang dipengaruhi oleh beberapa faktor diantaranya adanya pandemi Covid-19, pengeluaran konsumsi rumah tangga melambat, dan menurunnya sektor pariwisata. Adapun tabel jumlah kemiskinan di Indonesia menurut (Badan Pusat Statistik, 2020)

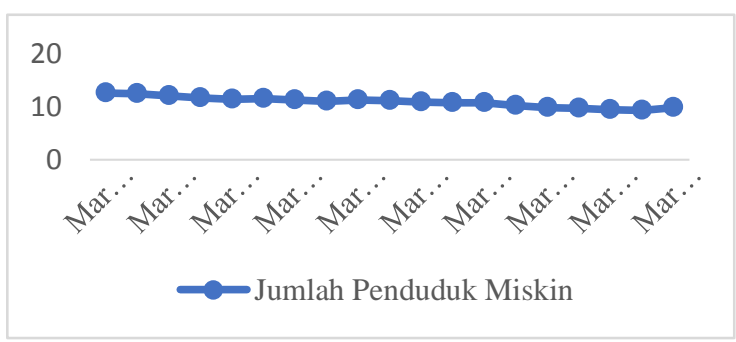

Tabel 1. Grafik Penduduk Miskin Indonesia periode 2011-2020, Sumber : BPS, periode 20112020 
Jika dilihat dari tabel tersebut pada periode September 2019 hingga Maret 2020, terjadi peningkatan kemiskinan sebesar 3,20\%. Sebagai bentuk upaya pemerintah dalam mengurangi kemiskinan dan kesenjangan dikeluarkan UUD 1945 Pasal 34 Ayat (1). Dijelaskan lebih lanjut pada Undang-undang No. 39 Tahun 1999 pada pasal 5 ayat (3) tentang Hak Asasi Manusia disebutkan bahwa yang termasuk kelompok rentan adalah lansia, anak-anak, fakir, miskin, wanita hamil, dan disabilitas. Realisasi terkait regulasi tersebut masih sangat terbatas, hal ini dapat dilihat pada Ratio Gini yang dirilis oleh BPS hingga periode Maret 2020 (Badan Pusat Statistik, 2020)

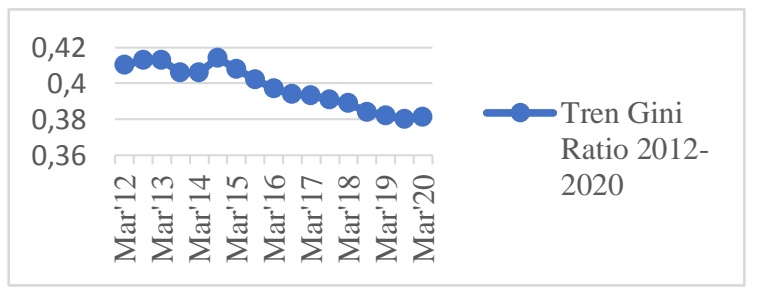

Tabel 2. Grafik Tren Gini Ratio Indonesia periode 2012-2020, Sumber : BPS, periode 20122020

Dari data tersebut dapat dilihat pada September 2019 gini ratio nilai indeksnya berada pada 0,380 sedangkan pada Maret 2020 nilai indeksnya menjadi 0,381. Menurut Badan Pusat Statistik (2020) meningkatnya nilai gini ratio pada tahun 2020 menandakan adanya peningkatan ketimpangan yang terjadi dibanding tahun 2019.

Dalam upaya mengurangi kesenjangan utamanya pada kelompok rentan, pemerintah melihat besarnya potensi pada sistem keuangan syariah dalam perspektif ekonomi makro (Bappenas, 2019). Dari berbagai negara di dunia, Indonesia merupakan salah satu negara yang penduduknya paling banyak menganut ajaran islam. Menurut Globalreligiousfutures (2020) jumlah penganut muslim di Indonesia sebesar $87 \%$ atau sekitar 229.620.000 jiwa dari keseluruhan penduduk sebesar 270.203.917 jiwa (Badan Pusat Statistik, 2020). Tingginya angka penduduk Indonesia yang beragama Islam menjadi potensi yang cukup baik untuk meningkatkan potensi sistem keuangan syariah Indonesia yang nantinya membantu pemerintah dalam mengurangi kesenjangan. Potensi dana zakat tahun 2019 sebesar Rp.233,8 Triliun dengan indikator zakat penghasilan menjadi nilai potensi paling besar yaitu sebesar Rp.139,07 Triliun, kemudian zakat uang sebesar Rp. 56,76 Triliun, zakat pertanian sebesar Rp. 19,79 Triliun, dan zakat peternakan sebesar Rp. 9,51 Triliun (Badan Amil Zakat Nasional, 2020). Besarnya potensi zakat harus diimbangi dengan ketepatan dalam penyalurannya agar dapat mencapai tujuan sosial sehingga kesenjangan di masyarakat dapat berkurang secara signifikan.

Allah menurunkan aturan terkait harta untuk dipergunakan sebaik mungkin salah satunya melalui instrumen Zakat. Zakat memiliki nilai ibadah dalam sisi sosial selain itu berdampak baik bagi kesejahteraan masyarakat (Ridlo, 2014). Firman Allah terkait zakat dijelaskan pada Q.S. At-Taubah Ayat 60 :

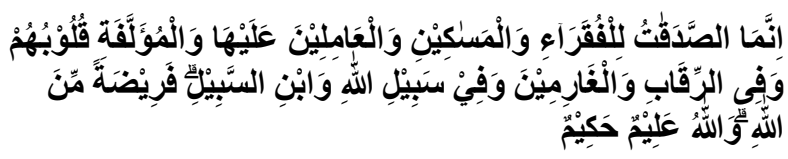

Artinya : "Sesungguhnya zakat itu hanyalah untuk orang-orang fakir, orang miskin, amil zakat, yang dilunakkan hatinya (mualaf), untuk (memerdekakan) hamba sahaya, untuk (membebaskan) orang yang berutang, untuk jalan Allah dan untuk orang yang sedang dalam perjalanan, sebagai kewajiban dari Allah. Allah Maha Mengetahui, Maha bijaksana." (Q.S. AtTaubah Ayat 60)

Makna dari ayat tersebut Allah memerintahkan kepada golongan yang mampu berzakat dengan memberikan zakatnya tepat sasaran yaitu kepada 8 golongan. Tepat sasaran menjadi tolok ukur dimana ketika segala sesuatu yang diniatkan baik dan terlaksananya dengan baik maka diharapkan tujuan dapat tercapai sebagaimana yang diinginkan. Zakat tidak hanya sebagai bentuk ketaatan, akan tetapi juga sebagai bentuk social responsibility atau bentuk kepedulian kepada sesama manusia. Zakat mengandung nilai sosial ekonomi yang sangat besar. Namun, kenyataan yang ada di masyarakat zakat menjadi suatu amal pribadi dimana keputusan bergantung individu. Melihat kondisi yang ada di lapangan, maka perlu untuk dilakukan pengorganisasian zakat secara tertib agar nantinya dana zakat yang telah dihimpun dapat sesuai dengan potensi yang ada, serta penyalurannya dapat tepat sasaran (Badriah, 2019). Menurut Clarashinta Canggih dkk (2017) terjadinya kesenjangan antara potensi dan realisasi zakat dikarenakan faktor rendahnya kepercayaan masyarakat kepada lembaga. Untuk itu dalam memenuhi dan merealisasikan kewajiban yang ada, pemerintah membutuhkan 
kelompok masyarakat atau lembaga yang dapat mengelola secara profesional dana zakat.

Untuk memudahkan pemerintah dalam membantu mengelola zakat sesuai dengan UU Nomer 23 tahun 2011, BAZNAS mengeluarkan Peraturan Nomer 3 tahun 2014 terkait Organisasi dan Tata Kerja BAZNAS Kabupaten atau Kota. Pemerintah Kabupaten Mojokerto menindaklanjuti peraturan tersebut dengan mengeluarkan Surat Keputusan Bupati Mojokerto Nomer $188.45 / 567 / \mathrm{HK} / 416-012 / 2018$ pada tanggal 20 Desember 2018 tentang pendirian BAZNAS Kabupaten Mojokerto. Sebelumnya, Kabupaten Mojokerto pernah memiliki BAZ yang berada dalam pengawasan Kementerian Agama Kabupaten Mojokerto, namun pada tahun 2017 kekosongan kepemimpinan menyebabkan BAZ Kabupaten Mojokerto tidak aktif hingga akhirnya dikeluarkan Surat Keputusan Bupati Mojokerto tentang Pendirian BAZNAS Kabupaten Mojokerto sehingga BAZNAS di Kabupaten Mojokerto kembali aktif.

Kembalinya BAZNAS di wilayah Kabupaten Mojokerto merupakan hal yang sangat baik dalam membantu pemerintah untuk mengurangi kesenjangan yang ada utamanya di wilayah Kabupaten Mojokerto. Menurut BPS Kabupaten Mojokerto (Juni, 2020) penduduk muslim di wilayah Kabupaten Mojokerto sebesar 1.125.760 jiwa dari penduduk keseluruhan sebesar 1.159.593 jiwa (Dispenduk Capil Kab. Mojokerto, 2020). Sementara itu terkait dengan kelompok rentan (penduduk miskin) yang ada di wilayah Kabupaten Mojokerto berikut gambar grafik :

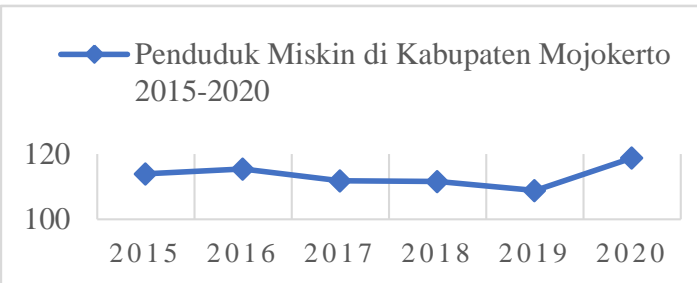

Tabel 3. Grafik Penduduk Miskin Kab.

Mojokerto, Sumber : BPS, periode 2015-2020

Dapat dilihat dari tersebut dapat dilihat penduduk miskin di Kabupaten Mojokerto sebesar antara 100 ribu jiwa sampai dengan 120 ribu jiwa sementara penduduk muslim di Kabupaten Mojokerto sebesar 1.125.760 jiwa artinya dengan banyaknya penduduk muslim di Kabupaten Mojokerto merupakan suatu potensi yang besar dalam optimalisasi penghimpunan dan penyaluran dana zakat di Kabupaten Mojokerto. Sementara itu terhitung sejak BAZNAS Kabupaten Mojokerto resmi beroperasi pendapatan BAZNAS Kabupaten Mojokerto dari Januari tahun 2020 hingga Januari tahun 2021 seperti pada grafik :

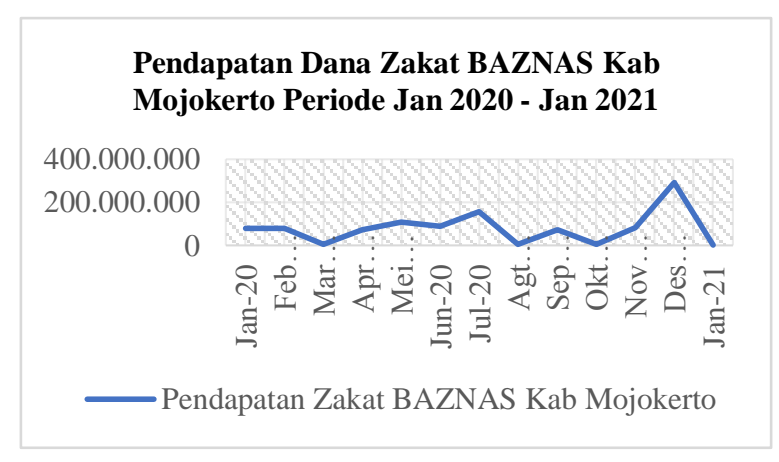

Tabel 4. Grafik Pendapatan Dana Zakat BAZNAS Kabupaten Mojokerto, Sumber : Data Internal BAZNAS Kab. Mojokerto

Dari data tersebut terlihat terdapat ketimpangan pemasukan zakat dilihat dari penurunan tajam grafik pendapatan dana zakat bulan Desember tahun 2020 yaitu sebesar Rp. 290.717.338 di bulan Januari 2021 hanya mendapat Rp. 1.350.000. Menurut staff keuangan BAZNAS Kabupaten Mojokerto Ibu Ayu Anggraini, S.H.I. penurunan tersebut dikarenakan setiap bulannya masih banyak muzakki yang setor zakat dengan sistem rapel. Hal ini tentu akan sangat berdampak terhadap penyaluran dana kepada mustahiq.

Menurut Hafidhuddin (2011) salah satu strategi dalam meningkatkan potensi zakat adalah dengan menguatkan amil zakat dalam hal ini BAZNAS. Jika dilihat dari data penghimpunan dana zakat selain faktor kurangnya kesadaran masyarakat faktor amil zakat juga menjadi faktor utama belum terlaksana dengan baik penghimpunan zakat yang ada di BAZNAS Kabupaten Mojokerto, database yang tidak akurat dan tidak up to date berdampak pada kurang optimalnya penghimpunan dan penyaluran dana dikarenakan dalam hal pemetaan tidak dapat berjalan dengan baik. Hal ini memunculkan pertanyaan dalam diri peneliti Bagaimana peran BAZNAS Kabupaten Mojokerto selama ini dalam melindungi Kelompok Rentan (Fakir dan Miskin) dan Mengurangi Kesenjangan yang ada di Kabupaten Mojokerto dan apakah penyaluran zakat yang dilaksanakan oleh BAZNAS Kabupaten Mojokerto telah terlaksana dengan baik dan tepat sasaran. Berdasarkan uraian diatas, penelitian ini berusaha mengungkap peran BAZNAS Kabupaten Mojokerto dalam melindungi kelompok rentan 
(mustahiq zakat) dan mengurangi ketimpangan yang ada di Kabupaten Mojokerto. Lokasi penelitian yaitu Kabupaten Mojokerto dipilih karena permasalahan yang ditemukan penulis berada di Badan Amil Zakat Nasional (BAZNAS) Kabupaten Mojokerto.

\section{METODE PENELITIAN}

Peneliti menerapkan pendekatan kualitatif deskriptif dengan metode studi kasus. Menurut Rahmat, P.S. (2009:7) penelitian studi kasus memiliki batasan yang sangat rinci, pengambilan data secara mendalam, dan menyertakan berbagai informasi sumber untuk mendukung penelitian. Lokasi yang dipilih untuk penelitian ini yaitu Badan Amil Zakat Nasional (BAZNAS) Kabupaten Mojokerto yang beralamat di Jalan A Yani No.16 Mojokerto (61318) Margelo, Magersari, Mojokerto. Sementara waktu pelaksanaan penelitian dilaksanakan mulai dari bulan Juni 2020 karena peneliti melakukan observasi secara mendalam lalu pada bulan Januari 2021 peneliti mulai melaksanakan tahap wawancara sampai data atau informasi yang dibutuhkan oleh peneliti telah dapat terpenuhi. Data primer dipilih penulis sebagai sumber data yang digunakan dalam penelitian ini. Menurut Sugiyono (2017) data primer merupakan data yang diperoleh langsung dari reponden terkait. Data primer dipilih oleh peneliti untuk memudahkan peneliti dalam melakukan analisis secara lebih mendalam.

Dalam mengumpulkan data yang dibutuhkan, peneliti menggunakan teknik observasi, teknik wawancara, dan teknik dokumentasi. Teknik observasi dilakukan untuk mendapatkan gambaran dari suatu kejadian, sementara itu teknik wawancara dilakukan sebagai checking dari gambaran yang telah didapatkan sebelumnya, dan yang terakhir teknik dokumentasi dilakukan sebagai tambahan data atau penguat dari data yang telah didapatkan sebelumnya berupa foto, surat, dan sebagainya (Rahmat, 2009). Observasi yang dilakukan oleh peneliti dengan menjadi staff sementara (Magang) dengan tujuan mengamati permasalahan yang ada sehingga peneliti dalam melakukan penelitian tidak mengalami keragu-raguan ditengah penelitian. Selanjutnya, peneliti melaksanakan wawancara dengan Ketua BAZNAS Kabupaten Mojokerto, Kepala Kantor BAZNAS Kabupaten Mojokerto, Staff Bagian Administrasi dan Keuangan BAZNAS Kabupaten Mojokerto, serta empat orang Mustahiq (Kelompok Rentan) BAZNAS Kabupaten Mojokerto yang telah menerima manfaat dengan batasan waktu lebih dari satu tahun. Dokumentasi yang diperoleh oleh peneliti terkait Jumlah UPZ BAZNAS, LAZ BAZNAS, serta dokumentasi lain pendukung penelitian. Untuk uji validitas peneliti menggunakan Teknik Triangulasi Teknik dan Triangulasi Sumber. Menurut model Miles dan Huberman (dalam Sugiyono, 2017:246-253) Teknik analisis data yang digunakan oleh peneliti melalui tiga alur yaitu reduksi atau pemilihan data setelah selesai tahap selanjutnya data tersebut dirangkum, terakhir data tersebut diuraikan dan dilakukan penarikan kesimpulan.

\section{HASIL DAN PEMBAHASAN}

\subsection{Hasil Penelitian}

Hasil yang diperoleh peneliti dari penelitian mengenai Peran Baznas dalam Melindungi Kelompok Rentan dan Mengurangi Kesenjangan yang dilaksanakan di BAZNAS Kabupaten Mojokerto dengan melakukan observasi, wawancara, dan dokumentasi dalam pembahasan ini penulis akan menjabarkan serta menganalisis hasil penelitian tersebut.

\section{Peran BAZNAS Kabupaten Mojokerto dalam Penghimpunan Zakat, Infaq, dan Shodaqoh (ZIS)}

Berdirinya suatu lembaga pemerintah nonstruktural yaitu Badan Amil Zakat Nasional (BAZNAS) berdasarkan Keputusan Presiden Republik Indonesia Nomor 8 Tahun 2001 merupakan suatu bentuk keseriusan pemerintah dalam meningkatkan potensi-potensi yang ada untuk mengurangi kesenjangan yang terjadi di Indonesia. Kemudian untuk memperkuat kembali peran BAZNAS pemerintah mengeluarkan Undangundang Nomor 23 Tahun 2011 tentang Pengelolaan Zakat. Pada Undang-undang Nomor 23 Tahun 2011 Bagian Ketiga Pasal 15 disebutkan bahwa BAZNAS dalam membantu mempercepat pelaksanaan program pemerintah dalam pengentasan kelompok rentan memerlukan bantuan Organisasi Pemerintah Daerah (OPD) di setiap daerah dalam membentuk BAZNAS. Hal ini dijelaskan lebih rinci pada Peraturan Pemerintah Nomor 14 tahun 2014. Berdasarkan hasil wawancara dengan Bapak KH. Sholikin, S.Pd.I. selaku Ketua BAZNAS Kabupaten Mojokerto pada hari Selasa, 23 Februari 2021 :

"BAZNAS Kabupaten Mojokerto dibentuk ditandai dengan dikeluarkannya Surat Keputusan Bupati Kabupaten Mojokerto pada tanggal 20 Desember 2018 Nomer 188.45/567/HK/416- 
012/2018 tentang Pembentukan BAZNAS Kabupaten Mojokerto. Namun sejauh ini OPD Kabupaten Mojokerto hanya mengeluarkan Surat Keputusan Pembentukan, terkait Kebijakan dan lain-lain masih belum ada".

Pembentukan BAZNAS Kabupaten Mojokerto merupakan salah satu langkah baik yang dilakukan pemerintah Kabupaten Mojokerto dalam membantu meningkatkan kesejahteraan dan mengurangi kesenjangan yang ada ditingkat Kabupaten Mojokerto. Adanya zakat memiliki fungsi dan peran yang lebih luas tidak hanya terpaut pada satu atau dua hal saja. Dijelaskan lebih lanjut terkait fungsi dan peran zakat menurut M.A. Mannan dalam buku Ekonomi Islam Teori dan Praktik Dasar, adapun fungsi zakat antara lain : (1) Segi Moral : Zakat dapat mengurangi sifat serakah dalam diri setiap individu atau kelompok ; (2) Segi Sosial : Zakat dapat mengurangi kemiskinan di masyarakat ; (3) Segi Ekonomi : Zakat mencegah penimbunan kekayaan oleh individu atau kelompok. Zakat merupakan kewajiban muslim dalam hal ini mampu atau tidak kekurangan yang dapat dimanfaatkan sebagai sumber dana potensial bagi kesejahteraan bersama (Hafidhuddin dalam Niamulloh 2013, 78). Menurut Hafidhuddin (2011) Untuk menggali potensi zakat diperlukan empat cara yang harus dilakukan secara serentak diantaranya :

1) Menyelenggarakan sosialisasi kepada masyarakat terkait dengan makna, hukum, nishab atau perhitungan, serta hikmah zakat.

2) Menguatkan amil zakat agar dapat menjadi amil yang amanah, dan profesional

3) Menyalurkan zakat dengan tepat sasaran sesuai ketentuan syariah dan juga transparan

4) Menyelenggarakan koordinasi yang baik antar amil zakat (tingkat daerah, nasional, regional, dan internasional) maupun dengan komponen yang lain.

Sebagai bentuk implementasi atas potensi yang ada BAZNAS Kabupaten Mojokerto terus mengupayakan pengoptimalan pengelolaan zakat dengan salah satunya mengadakan sosialisasi tentang optimalisasi fungsi kelembagaan dan target penghimpunan zakat, infaq, dan shodaqoh pada bulan Juni tahun 2020. Hal ini sesuai dengan salah satu upaya yang dijelaskan oleh Hafidhuddin sebelumnya yaitu terkait penguatan amil zakat. Allah SWT menjelaskan terkait amanah harus dilaksanakan dengan sebaik dan seadil mungkin pada Surah An-Nisa' Ayat 58 :

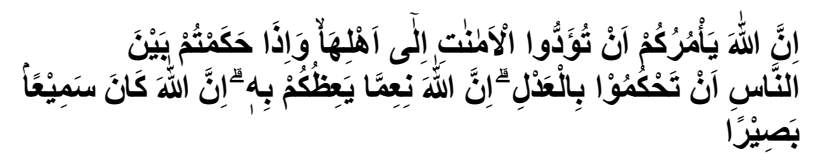

Artinya : "Allah menyuruh kamu untuk menghantarkan amanah kepada yang memiliki hak untuk menerima, dan bilamana kamu menetapkan suatu hukum di antara mereka sekiranya kamu menetapkan dengan adil. Allah sebaik yang memberi pengajaran kepadamu. Maha Mendengar lagi Maha Melihat." (Q.S. An-Nisa' Ayat 58)

Selanjutnya, untuk mengetahui lebih detail tentang BAZNAS Kabupaten Mojokerto peneliti melaksanakan wawancara dengan Kepala Kantor BAZNAS Kabupaten Mojokerto H. Khafidz Busyri pada hari Selasa, 23 Februari 2021 terkait kriteria muzakki BAZNAS Kabupaten Mojokerto dan jenis zakat yang dihimpun antara lain :

"Kriteria Muzakki BAZNAS Kabupaten Mojokerto adalah Siapapun orang muslim, sudah mencapai nishab, mukallaf, dan bersedia menyalurkan Zakat. Adapun Zakat, Infaq, dan Shodaqoh yang dihimpun oleh BAZNAS Kabupaten Mojokerto sejauh ini Zakat Fitrah dan Zakat Maal. Zakat Maal dalam hal ini disebut Zakat Profesi di BAZNAS Kabupaten Mojokerto dihimpun dari Zakat Profesi ASN selingkup KEMENAG, dengan beberapa non KEMENAG. Bagi ZIS dibawah Rp.80.000 otomatis masuk ke infaq, namun jika diatas Rp. 80.000 masuk Zakat Profesi (dengan standart nishab tersebut)"

Sementara itu, untuk menjelaskan lebih lanjut Rekapitulasi Dana ZIS dari tahun 2019 hingga tahun 2020 terkait keuangan di BAZNAS Kabupaten Mojokerto peneliti melakukan wawancara dengan Staff Keuangan BAZNAS Kabupaten Mojokerto Ayu Anggraini, S.HI. pada hari Rabu, 24 Februari 2021 mengatakan bahwa :

"Dana yang berhasil dihimpun oleh BAZNAS Kabupaten Mojokerto sejauh ini sudah mengalami peningkatan yang cukup baik, Di Tahun 2020 BAZNAS berhasil menghimpun Rp.1.048.756.956 Milyar dana Zakat dengan Sisa dari tahun sebelumnya 2019 sebesar Rp. 110.000.000. Namun sebenarnya ini masih jauh dari target"

Ayu Anggraini, S.H.I. juga menjelaskan terkait perbedaan pendapatan penghimpunan yang sangat signifikan disetiap bulannya disebabkan muzakki me-rapel pembayaran dibulan selanjutnya. Hal ini dikonfirmasi oleh Kepala Kantor H. Khafidz Busyri, 
penghimpunan Zakat di BAZNAS Kabupaten Mojokerto belum maksimal dikarenakan banyak kendala termasuk target utama BAZNAS menghimpun dana dari Aparatur Sipil Negara (ASN) belum dapat terlaksana disetiap instansi dikarenakan belum ada Peraturan Daerah Kabupaten Mojokerto yang dapat menguatkan hal tersebut.

Sebagai upaya lain untuk meningkatkan penghimpunan zakat BAZNAS Kabupaten Mojokerto membentuk Unit Pengumpul Zakat (UPZ) yang didasarkan pada Peraturan BAZNAS Nomor 2 tahun 2016 tentang Pembentukan UPZ dan Pengelolaan UPZ. Dari data yang didapatkan oleh peneliti sumber Staff Administrasi dan Data Bapak Luqman Baroroh pada hari Selasa, 23 Februari 2021, sejauh ini BAZNAS Kabupaten Mojokerto memiliki 20 UPZ diantaranya : (1) Kecamatan Sooko, (2) Kecamatan Pacet, (3) RSUD Prof Dr. Soekandar, (4) Dinas Pendapatan Daerah, (5) SMKN 1 Mojoanyar, (6) PDAM, (7) Dinas Tenaga Kerja, (8) PT. BPR Majatama, (9) Dinas Kesehatan, (10) SMAN 1 Gondang, (11) Dinas Komunikasi Dan Informatika, (12) Musholla Istiqomah Tuwiri Mojosari, (13) Badan Perencanaan Pembangunan Daerah, (14) Dinas Pekerjaan Umum Dan Penataan Ruang, (15) Kecamatan Gedeg, (16) Dinas Perindustrian Dan Perdagangan, (17) Dinas Perpustakaan Dan Kearsipan, (18) Badan Penanggulangan Bencana Daerah, (19) Dinas Pangan Dan Perikanan, (20) Dinas Koperasi Dan Usaha Mikro.

Selain Unit Pengumpul Zakat (UPZ), BAZNAS Kabupaten Mojokerto juga berkordinasi dengan LAZ terkait pengelolaan zakat yang berada di Kabupaten Mojokerto. Berdasarkan wawancara dengan H. Khafidz Busyri pada hari Selasa, 23 Februari 2021 didapatkan bahwa BAZNAS Kabupaten Mojokerto sejauh ini berkoordinasi dengan 7 LAZ yang dikuatkan dengan adanya undang-undang BAZNAS, diantaranya (1) YPI Bina Madani/ Lembaga Pengembangan Infaq, (2) LAZISMU Kabupaten Mojokerto, (3) LAZISNU Kabupaten Mojokerto, (4) Lembaga Manajemen Infaq, (5) Yatim Mandiri, (6) Baitul Maal Hidayatulloh, (7) Yayasan Lentera Hati AlHaromain. Adapun kebijakan yang telah ditetapkan oleh BAZNAS Kabupaten Mojokerto terhadap LAZ antara lain : setiap LAZ melaporkan laporan secara berkala kepada BAZNAS Kabupaten, yang kemudian diteruskan oleh BAZNAS Kabupaten Mojokerto ke BAZNAS Provinsi.
Dari hasil observasi, wawancara, dan dokumentasi terkait Peran BAZNAS Kabupaten Mojokerto dalam Penghimpunan Zakat dengan Kepala Kantor, Staff Keuangan, dan Staff Admin dan Data, diperoleh bahwa BAZNAS Kabupaten Mojokerto dari segi Penghimpunan mengalami eskalasi cukup baik dapat dilihat perolehan dana Zakat pada Tahun 2020 BAZNAS berhasil mencapai Rp.1.048.756.956 Milyar dana Zakat dengan Sisa dari tahun sebelumnya 2019 sebesar Rp. 110.000.000. Melihat kurun waktu yang masih terbilang baru BAZNAS Kabupaten Mojokerto telah menjalankan fungsi dalam hal penghimpunan dengan cukup baik. BAZNAS Kabupaten Mojokerto juga telah menjalankan aturan seperti halnya pendirian UPZ BAZNAS sesuai dengan Peraturan BAZNAS Nomor 2 tahun 2016 tentang Pembentukan UPZ dan Pengelolaan UPZ, koordinasi BAZNAS dengan LAZ sesuai dengan Undang-Undang Nomor 23 tahun 2011 Pasal 19 disebutkan bahwa Lembaga Amil Zakat dalam Hal ini LAZ wajib melaporkan laporan yang telah diaudit secara berkala kepada BAZNAS terkait pelaksanaan pengumpulan, pendistribusian, dan pendayagunaan zakat. Catatan terpenting dari peran BAZNAS Kabupaten Mojokerto segi penghimpunan adalah kurang optimalnya penghimpunan dengan potensi yang ada di Kabupaten Mojokerto sehingga hal ini tentu saja perlu adanya tindak lanjut tidak hanya bagi BAZNAS Kabupaten Mojokerto sebagai amil zakat tetapi juga Pemerintah Daerah Kabupaten Mojokerto dimana penghimpunan yang ada harus didukung sinergi yang baik dari berbagai pihak.

\section{Peran BAZNAS Kabupaten Mojokerto dalam Penyaluran dan Pendayagunaan Zakat, Infaq, dan Shodaqoh (ZIS)}

Laju pertumbuhan penduduk di Indonesia tercatat pada September 2020 sebesar 270,20 juta jiwa dimana selama 10 tahun terakhir laju pertumbuhan penduduk meningkat sebesar 32,56 juta jiwa (Badan Pusat Statistik, 2020). Tingginya laju pertumbuhan penduduk berdampak negatif bagi pertumbuhan ekonomi (Waluyo, 2004). Pertumbuhan ekonomi erat kaitannya dengan keadilan dalam distribusi, namun yang terjadi di masyarakat bertolak belakang dengan teori yang ada dimana ketidakadilan dan kesenjangan distribusi pendapatan yang berdampak pada meningkatnya angka kemiskinan (Aprianto, 2016). Islam mengajarkan nilai-nilai keadilan dimana suatu harta tidak diperbolehkan hanya terpusat pada sekelompok orang saja. Pentingnya keadilan dalam hal ini 
distribusi kekayaan berdampak baik bagi menurunnya angka kesenjangan ekonomi. Allah menjelaskan terkait larangan untuk berlebih-lebihan dan pentingnya melaksanakan zakat pada Surat AlAn'am Ayat 141 :



Artinya : "Dan (Allah) yang menciptakan tanaman yang merambat dan yang tidak merambat, pohon kurma, tanaman yang pelbagai rasa, zaitun dan delima yang seiras (bentuk dan warnanya) dan tidak seiras (rasanya). Makanlah buahnya apabila berbuah dan berikanlah haknya (zakatnya) pada saat memetik hasilnya, tapi janganlah berlebihlebihan. Sesungguhnya Allah tidak menyukai orangorang yang berlebihan." (Q.S. Al-An'am Ayat 141)

Upaya dalam mencapai kesejahteraan salah satunya dengan pembangunan ekonomi bagi suatu wilayah atau negara. Terlaksananya pembangunan ekonomi menandakan adanya pembaruan keadaan untuk lebih baik dari sebelumnya, adanya pembangunan ekonomi berpengaruh pada meningkatnya kesejahteraan pada suatu wilayah atau negara (Todaro \& Smith, 2011). Dengan adanya kebijakan pendistribusian secara adil dan menyeluruh diharapkan kesejahteraan dapat tercapai. Kebijakan distribusi memerlukan dukungan dari bebagai pihak dalam lingkup ini pemerintah dan masyarakat (Ruslan dalam Naerul, 2012). Salah satu bentuk upaya pemerintah dalam pembangunan ekonomi dengan mengoptimalkan potensi yang ada untuk mengurangi kesenjangan yaitu dengan menyelenggarakan distribusi keadilan melalui BAZNAS. Dari hasil wawancara yang dilakukan peneliti dengan $\mathrm{H}$. Khafidz Busyri pada hari Selasa, 23 Februari 2021 dijelaskan bahwa Kelompok rentan adalah orang-orang yang membutuhkan untuk kebutuhan sehari-hari. Dalam hal ini BAZNAS Kabupaten Mojokerto dengan dana penghimpunan yang masih minim arahnya lebih kepada hifdzul nafis atau dalam Maqashid Syariah sebagai kebutuhan dasar manusia (makan sehari-hari). Adapun kriteria Kelompok Rentan menurut BAZNAS Kabupaten Mojokerto :

1) KKM (Komunitas Keluarga Madani) : Berjumlah 292 orang terbagi dari 14 kecamatan di Kabupaten Mojokerto. KKM ini merupakan program yang dijalankan oleh BAZNAS
Kabupaten Mojokerto dengan dana dari BAZNAS Provinsi Jawa Timur. Program ini dimaksudkan untuk membantu dalam hal pemberian modal kerja sejumlah Rp.1 juta (pada awal saja) dan dikembangkan secara berkelompok. Program ini dijalankan juga dengan mengajarkan kepada penerimanya untuk gemar bersedekah meskipun sedikit yaitu sebesar Rp. 1000 setiap harinya. Dari uang sedekah dari tiap-tiap KKM nanti dikumpulkan dan dapat diberikan kepada calon anggota KKM yang baru dengan nominal Rp. 1 Juta.

2) Mustahiq Konsumtif : Berjumlah 180 orang terbagi dari 14 kecamatan di Kabupaten Mojokerto. Program ini dijalankan oleh BAZNAS Kabupaten Mojokerto dengan dana yang berhasil dihimpun BAZNAS Kabupaten Mojokerto. Program ini dimaksudkan untuk santunan biaya hidup sebesar Rp. 100.000 setiap bulannya.

3) Mustahiq Kriteria B : Berjumlah 9 orang terbagi dari 14 kecamatan di Kabupaten Mojokerto. Program ini dijalankan oleh BAZNAS Kabupaten Mojokerto dengan dana yang berasal dari BAZNAS Provinsi Jawa Timur. Program ini dimaksudkan untuk santunan biaya hidup tiap bulan dengan kriteria penerima miskin sebatang kara dan tidak ada yang membiayai hidup sebesar Rp. 400.000 setiap bulannya.

4) Mustahiq Kriteria A : Berjumlah 11 orang terbagi dari 14 kecamatan di Kabupaten Mojokerto. Program ini dijalankan oleh BAZNAS Kabupaten Mojokerto dengan dana yang berasal dari BAZNAS Provinsi Jawa Timur. Program ini dimaksudkan untuk santunan biaya hidup tiap bulan dengan kriteria penerima miskin sebatang kara Tidak ada yang membiayai hidup usia diatas 65 tahun sebesar Rp. 600.000 setiap bulannya."

Bapak H. Khafidz Busyri selaku kepala Kantor BAZNAS Kabupaten Mojokerto menjelaskan lebih lanjut terkait Strategi BAZNAS Kabupaten Mojokerto dalam penyaluran dana Zakat, Infaq, dan Shodaqoh yaitu dengan menjalankan program Gerakan Filantropi dengan adaptasi 8 asnaf dikembangkan dengan 5 gerakan, tasarruf atau tekanannya" Adapun beberapa program tersebut diantaranya :

1) Kabupaten Mojokerto PEDULI, merupakan program yang dijalankan oleh BAZNAS Kabupaten Mojokerto dalam misi kemanusiaan. Adapun program diantaranya : Santunan Rutin 
Fakir Dhu'afa', Bedah Rumah Tinggal Dhu'afa', Tanggap Siaga Bencana, Rantang Rangsum Dhu'afa'

2) Kabupaten Mojokerto SEHAT, merupakan program yang dijalankan oleh BAZNAS Kabupaten Mojokerto dalam misi Kesehatan. Adapun program diantaranya : Bantuan Biaya Kesehatan, Klinik Pengobatan Gratis Mustahiq, Bakti Sosial Pengobatan, Pendampingan Pola Hidup Sehat

3) Kabupaten Mojokerto CERDAS, merupakan program yang dijalankan oleh BAZNAS Kabupaten Mojokerto dalam misi meningkatkan Sumber Daya Manusia (SDM) di wilayah Kabupaten Mojokerto. Adapun program diantaranya : Bantuan Beasiswa SD/MI - SMP/MTs, Bantuan Guru Ngaji/Tutor Bimbel Gratis, Bedah Layak Sarana Madrasah/Sekolah, Program Satu Keluarga Satu Sarjana

4) Kabupaten Mojokerto TAQWA, merupakan program yang dijalankan oleh BAZNAS Kabupaten Mojokerto dalam misi mengembangkan aqidah serta akhlaq. Adapun program diantaranya : Khidmad Syi'ar Cinta Yatim, Da'wah Kampung Rawan Aqidah, Bedah Layak Sarana Ibadah, Khidmat Majid, Training Motivasi Taqwa

5) Kabupaten Mojokerto MAKMUR, merupakan program yang dijalankan oleh BAZNAS Kabupaten Mojokerto dalam misi meningkatkan kreatifitas serta memberdayakan mustahiq. Adapun program diantaranya: Bantuan Wirausaha Berbasis Jamaah, Bantuan Alat/Modal Kerja, Kampung BAZNAS Berdaya, Training Keterampilan Usaha

Dari kelima strategi penyaluran dana zakat yang ada BAZNAS Kabupaten Mojokerto sejauh ini yang terlaksana diantaranya : (1) Santunan Rutin Fakir Dhu'afa' atau pemberian dana kepada mustahiq konsumtif sebesar Rp. 100.000 setiap bulan; (2) Bedah Rumah Tinggal Dhu'afa', Tanggap Siaga Bencana seperti Kebakaran salah satunya dilaksanakan di Kecamatan Jetis Kabupaten Mojokerto; (3) Klinik Pengobatan Gratis Mustahiq yang dilaksanakan di Kecamatan Bangsal dan Kecamatan Pacet pada tahun 2019-2020; (4) Syi'ar Cinta Yatim; (5) Bantuan Alat atau Modal Kerja atau pemberian dana kepada KKM (Komunitas Keluarga Madani). Sejauh ini dengan dana yang ada BAZNAS Kabupaten Mojokerto belum dapat menjalankan strategi penyaluran Kabupaten Mojokerto Cerdas dikarenakan masih terkendala dengan dana yang dihimpun disetiap bulannya.
Maka dari itu dalam hal penyaluran dana zakat BAZNAS Kabupaten Mojokerto masih berfokus pada pemberian bantuan dana secara langsung kepada Kelompok Rentan yang masih terkendala dalam memenuhi kebutuhan dasarnya. Hal ini sesuai dengan pendapat Al-Syatibi dalam Subagiyo (2016) mengenai kebutuhan dasar manusia ada 3 macam yaitu Dharuriyat, Hajiyat, Tahsiniyat. BAZNAS Kabupaten Mojokerto dengan potensi yang ada untuk melindungi serta mengurangi kesenjangan pada kelompok rentan mendahulukan kebutuhan dasar Dharuriyat. Dimana hal ini sebelumnya telah dijelaskan oleh Allah SWT pada Surah Al-Baqarah Ayat 179:

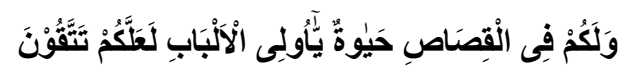

Artinya : "Dan dalam pembalasan (Qisas) terdapat suatu jaminan kehidupan bagi kamu, maka orang yang berakal hal tersebut agar kamu bertakwa"(Q.S. Al-Baqarah Ayat 179)

Makna dari ayat tersebut menjelaskan tujuan dharuriyat adalah tujuan utama mencapai keabadian bagi manusia, kelima kebutuhan dharuriyah ini harus dapat terpenuhi, jika salah satu kebutuhan tersebut diabaikan dapat menyebabkan ketidakseimbangan dalam kehidupan (Subagiyo, 2016). BAZNAS Kabupaten Mojokerto dalam mengelola zakat dapat dikatakan sudah sesuai dan cukup baik mengingat berbagai program yang telah berjalan sedikit banyak telah membantu Pemerintah Daerah Kabupaten Mojokerto dalam Melindungi Kelompok Rentan dan Mengurangi Kesenjangan di Kabupaten Mojokerto meskipun dampaknya masih belum terlihat optimal.

\section{Kelompok Rentan sebagai Penerima Bantuan Dana dari BAZNAS Kabupaten Mojokerto}

Adapun berikut hasil observasi dan wawancara yang telah dilaksanakan peneliti dengan kaum rentan sebagai penerima bantuan dana yang dimaksudkan oleh BAZNAS Kabupaten Mojokerto diantaranya :

1) KKM (Komunitas Keluarga Madani), berdasarkan hasil wawancara dengan Ibu Meiyani (Wiraswasta) pada hari Kamis 25 Februari 2021 di Desa Batan Krajan Kecamatan Gedeg Kabupaten Mojokerto selaku penerima bantuan BAZNAS sebagai modal usaha menuturkan bahwa : "Saya mendapatkan bantuan dari BAZNAS Kabupaten Mojokerto kurang lebih dari tahun 2019. Alhamdulillah dari sisi perekonomian BAZNAS Kabupaten Mojokerto membantu. Selain mendapat manfaat 
saya juga dapat belajar dalam hal sedekah, jadi sistem yang diberikan BAZNAS itu uang yang diberikan hanya sekali dengan syarat kita mendaftarkan usaha kita nanti jika disetujui kita diberi uang $R p$. 1.000.000, dari uang tersebut setiap bulannya kita (KKM) wajib untuk sedekah sejumlah seribu disetiap harinya, setelah terkumpul dari semua KKM uang tersebut akan diberikan lagi kepada mustahiq produktif (KKM Baru) yang berhak menerima. Alhamdulillah diajari sedekah dari Rp. 1.000 rupiah. Kalau bisa depan BAZNAS mengadakan pengembangan keterampilan untuk KKM"

2) Mustahiq Konsumtif, berdasarkan hasil wawancara dengan Ibu Siami di Desa Balongsari Kecamatan Gedeg Kabupaten Mojokerto pada hari Kamis, 25 Februari 2021 menuturkan bahwa : "Kinten-kinten sampun enten sepuluh wulan kantuk ndugi BAZNAS. Alhamdulillah, saget damel tambahan nedho. Mboten rutin, kinten-kinten nggeh sampun kantuk ping pitu, tapi Januari 2021 mboten kantuk, Februari kantuk tapi mboten double."

Bantuan yang telah diterima menurut penuturan Ibu Siami kurang lebih sudah 10 bulan dengan nominal bantuan Rp. 100.000,00. Ibu Siami bersyukur bisa mendapatkan bantuan. Namun Ibu Siami menambahkan bahwa jumlah bantuan tersebut tidak rutin didapatkan setiap bulannya. Hal ini dapat menjadi evaluasi untuk kinerja BAZNAS Kabupaten Mojokerto kedepan. Dimana penghimpunan sangatlah berpengaruh terhadap penyaluran dana dan kesejahteraan mustahiq atau dalam hal ini kelompok rentan.

3) Mustahiq Kriteria B, berdasarkan hasil wawancara dengan Bapak Kasbi di Kecamatan Puri Kabupaten Mojokerto pada hari Rabu, 24 Februari 2021 menuturkan : "Saya sudah mendapat bantuan selama setahun terakhir, dengan nominal Rp. 400.000,00, alhamdulillah dana yang disalurkan rutin tiap bulan dan sudah cukup untuk makan sehari-hari"

4) Mustahiq Kriteria A, berdasarkan hasil wawancara dengan Ibu Jami' di Desa Balongsari Kecamatan Gedeg Kabupaten Mojokerto pada hari Kamis, 25 Februari 2021 menuturkan bahwa : "Kurang lebih 1,5 tahun an iki nduk. Rutin, digawe cukup nggeh cukup mawon alhamdulillah. Bantuan yang diterima sebesar Rp. 600.000,00 setiap bulannya"

\subsection{Pembahasan}

\section{Ketepatan Peran BAZNAS Kabupaten Mojokerto dalam Melindungi Kelompok Rentan dan Mengurangi Kesenjangan}

Ketepatan peran BAZNAS Kabupaten Mojokerto pada penelitian ini dilihat dari peran BAZNAS Kabupaten Mojokerto sebagai pelaksana program baik penghimpunan maupun penyaluran zakat dan kelompok rentan dengan kriteria yang sudah disebutkan pada bab sebelumnya sebagai penerima program. Dari observasi dan wawancara yang didapatkan penulis dalam segi penghimpunan zakat BAZNAS Kabupaten Mojokerto telah melakukan upaya-upaya penghimpunan yang cukup baik diantaranya dengan mendirikan UPZ, bersinergi dengan LAZ, mengadakan sosialisasi tentang optimalisasi fungsi kelembagaan dan target penghimpunan zakat, infaq, dan shodaqoh pada bulan Juni tahun 2020, akan tetapi peneliti juga menemukan beberapa hal yang dapat menjadi bahan evaluasi BAZNAS Kabupaten Mojokerto kedepan, diantaranya :

1) BAZNAS Kabupaten Mojokerto masih terkonsentrasi dengan dana yang dihimpun di lingkungan Aparatur Sipil Negara (ASN) Kabupaten Mojokerto, padahal kendala besar yang dihadapi adalah belum ada Peraturan Daerah Kabupaten Mojokerto terkait yang mengharuskan ASN untuk wajib berzakat di BAZNAS Kabupaten Mojokerto.

2) Pencatatan penghimpunan dan penyaluran dana ZIS yang masih belum di informasikan secara transparan setiap bulannya melalui platform terkait menyebabkan minimalnya tingkat kepercayaan masyarakat kepada BAZNAS Kabupaten Mojokerto.

3) Menambah jumlah Sumber Daya Manusia (SDM) terutama dibagian penghimpunan (Fundrising)

4) Membuat aplikasi pengumpul zakat atau berkolaborasi dengan platform dompet digital yang sudah ada untuk memudahkan pembayaran sehingga dari segi penghimpunan dapat lebih maksimal.

Dalam penyaluran dan pendayagunaan zakat, BAZNAS Kabupaten Mojokerto telah melakukan upaya yang sangat baik diantaranya membentuk relawan untuk menguatkan kapasitas tim dalam melayani kelompok rentan. Sementara itu dari segi ketepatan penerima dana berdasarkan observasi dan wawancara yang telah dilakukan oleh peneliti, dari 4 
subjek penelitian peneliti tersebut dapat terkonfirmasi bahwa BAZNAS telah tepat memberikan bantuannya kepada Mustahiq dengan Kriteria yang telah ditetapkan oleh BAZNAS Kabupaten Mojokerto. Kriteria lain menurut Ahmad Farhan (2015) dalam Al-Quran disebutkan bahwa ada beberapa orang yang dikategorikan sebagai kelompok rentan, diantaranya; lanjut usia (Q.S. AlIsra' Ayat 23), janda miskin (Q.S. Al-Baqarah Ayat 240), berkebutuhan khusus atau cacat fisik (Q.S. AlBaqarah Ayat 177) dijelaskan lebih lanjut hal terpenting dari suatu kriteria adalah tetap memiliki korelasi dengan konsep kelompok rentan. Sedang dalam penelitian tersebut peneliti menemukan ketepatan dimana penerima bantuan tersebut memang benar orang yang dari segi ekonomi kekurangan dan membutuhkan bantuan untuk mencukupi kebutuhan hidupnya. Ibu Meiyani merupakan ibu rumah tangga yang pada awalnya berjualan tempe saat ini dapat mendirikan usaha toko kecil dan mampu untuk bersedekah Rp. 1000 per harinya. Bapak Kasbi penyandang tuna rungu yang tinggal seorang diri di rumah gubuk dan hanya mengandalkan bantuan dari tetangganya, Ibu Siami seorang ibu rumah tangga usia lanjut yang harus berjuang menjadi tulang punggung keluarga, Ibu Jami' yang tinggal seorang diri di rumah gubuk beralaskan tanah. Dari penelitian tersebut selain ketepatan dari segi kriteria kelompok rentan peneliti juga menemukan catatan khusus untuk pihak BAZNAS Kabupaten Mojokerto bahwa Ibu Siami (mustahiq konsumtif) yang memperoleh dana langsung dari BAZNAS Kabupaten Mojokerto sejumlah Rp. 100.000,00 mengkonfirmasi tidak mendapatkan bantuan dana secara rutin, hal ini menjadi catatan khusus BAZNAS Kabupaten Mojokerto agar kedepan dapat meningkatkan penghimpunan dana sehingga tidak ada lagi keterlambatan mustahiq dalam memperoleh haknya.

\section{KESIMPULAN}

Berdasarkan hasil penelitian terkait Analisis Peran Baznas dalam Melindungi Kelompok Rentan dan Mengurangi Kesenjangan (Studi Kasus Baznas Kabupaten Mojokerto) dapat disimpulkan :

1) Dalam melindungi Kelompok Rentan upaya yang dilakukan oleh BAZNAS Kabupaten Mojokerto sejauh ini sudah baik. Hal ini dibuktikan dengan adanya kriteria penerima bantuan BAZNAS seperti KKM, Mustahiq Konsumtif, Mustahiq Kriteria B, Mustahiq Kriteria A, menjadi salah satu kunci bahwa
BAZNAS Kabupaten Mojokerto memiliki target mustahiq yang jelas. Sehingga kedepan jika dalam penghimpunan Zakat, Infaq, dan Sedekah sudah lebih optimal dari sebelumnya hal ini tentu akan berdampak baik bagi kelompok rentan yang mendapat bantuan dana dari BAZNAS Kabupaten Mojokerto.

2) Dalam mengurangi Kesenjangan di Kabupaten Mojokerto BAZNAS Kabupaten Mojokerto dengan data yang ada saat ini belum dapat dikatakan mampu untuk mengurangi kesenjangan. Hal ini jika dilihat kembali dengan data penduduk miskin menurut (BPS, 2020) di wilayah Kabupaten Mojokerto sebesar 100 ribu jiwa sampai dengan 120 ribu jiwa namun penduduk yang telah mendapat bantuan dari BAZNAS kurang lebih 1000 orang dari berbagai kriteria, artinya masih $0,0086 \%$ belum mencapai $1 \%$ dari keseluruhan jumlah penduduk yang ada. Hal ini sejalan dengan penelitian yang dilaksanakan oleh Clarashinta Canggih dkk (2017) bahwa besarnya dana zakat yang diterima sampai dengan saat ini kurang dari $1 \%$ dari keseluruhan total potensi penerimaan zakat di Indonesia. Dengan sejumlah potensi yang ada dan mencapai milyaran bahkan triliyunan di lingkup nasional maupun regional, seharusnya tujuan besar ini dapat terealisasi di masa yang akan datang. Sebagai tangan dari BAZNAS Pusat tentu peran serta BAZNAS Kabupaten Mojokerto sangat diperlukan meskipun dalam mengurangi kesenjangan yang ada saat ini belum dapat dikatakan mampu, namun melihat upaya yang telah dilaksanakan oleh BAZNAS Kabupaten Mojokerto selama ini sudah cukup baik dan berhasil. BAZNAS Kabupaten Mojokerto juga menambahkan bahwa dalam hal ini bukan hanya menjadi tugas BAZNAS Kabupaten Mojokerto saja namun perlu adanya sinergitas yang terbentuk antara Lembaga/Instansi, UPZ, Relawan BAZNAS, Muzakki, dan utamanya Pemerintah Daerah Kabupaten Mojokerto selaku pemegang regulator agar dapat membantu tercapainya tujuan zakat untuk kesejahteraan umat.

Dengan adanya artikel ilmiah ini peneliti memberikan saran dapat menjadi bahan pertimbangan kedepan bagi berbagai pihak, diantaranya; dapat meningkatkan sinergi dan koordinasi antar BAZNAS Kabupaten Mojokerto dengan Pemerintah Daerah Kabupaten Mojokerto sebagai pemegang kebijakan. Adanya peraturan 
daerah yang mengatur tujuan utama dari BAZNAS Kabupaten Mojokerto untuk menghimpun dana ASN diharapkan dapat meningkatkan penghimpunan dan penyaluran zakat di Kabupaten Mojokerto. Selain itu, BAZNAS perlu meningkatkan layanan secara online terkait penghimpunan dan penyaluran zakat, mengingat saat ini kecanggihan teknologi dapat semakin memudahkan Muzakki dalam berzakat sebagai amil zakat harus dapat memanfaatkan keadaan dengan sangat baik.

\section{UCAPAN TERIMA KASIH}

Puji syukur kehadirat Allah SWT yang telah memberikan rahmat dan hidayah-Nya sehingga peneliti dapat menyelesikan karya dengan judul "Analisis Peran Baznas Dalam Melindungi Kelompok Rentan Dan Mengurangi Kesenjangan (Studi Kasus Baznas Kabupaten Mojokerto)". Penulis mengucapkan terima kasih kepada seluruh pihak yang telah membantu dan memberikan arahan, dukungan moral maupun materil dalam proses penelitian, dan penyusunan karya, sehingga dapat terselesaikan tepat waktu.

Kami selaku penulis berharap dengan selesainya Karya Akhir ini dapat memberikan dampak positif khususnya bagi peningkatan penghimpunan dan penyaluran zakat di Kabupaten Mojokerto. Selain itu, semoga karya ini dapat memberikan wawasan serta keilmuan baru pihak yang akan melaksanakan kajian atau penelitian mengenai zakat. Akhir kata penulis memohon maaf apabila dalam karya ini terdapat banyak kesalahan yang tidak disadari oleh penulis, penulis sangat berterima kasih jika terdapat suatu kritik maupun saran agar karya akhir ini dapat lebih baik lagi.

\section{REFERENSI}

Al-Qur'an Kemenag. (2020). Surah At-Taubah Ayat 60.

Aprianto, N. E. (2016). Kebijakan Distribusi dalam Pembangunan Ekonomi Islam. Al-Amwal, $\operatorname{VIII}(2), 437-456$.

Badan Amil Zakat Nasional. (2020). Outlook Zakat Indonesia. pp. 1-86. Diakses Januari 2021

Badan Amil Zakat Nasional. (2021). Dampak Zakat Terhadap Tingkat Kesejahteraan Mustahiq 2021.
Badan Pusat Statistik. (2020). Profil Kemiskinan Kabupaten Mojokerto Tahun 2020. BPS Kabupaten Mojokerto, (05), 1-6.

Badan Pusat Statistik. (2019). Jumlah Penduduk Menurut Keyakinan dan Agama yang Dianut.

Badan Pusat Statistik. (2020, Juli). Berita Resmi Statistik.

Badriah, L. S. (2019). Ketimpangan Distribusi Pendapatan dan Kaitannya dengan Pertumbuhan Ekonomi serta Faktor-Faktor yang Mempengaruhinya. Sustainable Competitive Advantage-9 (SCA-9) FEB UNSOED.

Bappenas. (2019). Membedah Angka Kemiskinan dan Kesenjangan: Rilis Terkini BPS. Siaran Pers. Jakarta: Kepala Biro Humas dan Tata Usaha Pimpinan.

Canggih, C., Fikriyah, K., \& Yasin, A. (2017). Potensi dan Realisasi Dana Zakat Indonesia. Al-Uqud: Journal of Islamic Economics, Vol 1 (1), 14-26.

Didin Hafidhuddin. (2011). Peran Strategis Organisasi Zakat Dalam Menguatkan Zakat Di Dunia 1 Didin Hafidhuddin. Vol 2 (1), 1-4.

Dispenduk Capil Kabupaten Mojokerto. Data \& Statistik Kependudukan di Kabupaten Mojokerto.

https://mojokertokab.go.id/datastatistik/kepend udukan Diakses pada 29 Maret 2021

Farhan, A. (2015). Al-Quran Dan Keberpihakan Kepada Kaum Duafa. Jurnal Imiyah Syi'ar, 15(2), 1-16.

Global Religious Future. (2020). Jumlah Penduduk Muslim di Indonesia. http://www.globalreligiousfutures.org/countrie s/indonesia\#/?affiliations_religion_id=0\&affili ations year $=2020 \&$ region name $=A 11 \% 20$ Coun $\begin{array}{lll}\text { tries\&restrictions year }=2016 & \text { Diakses } & 14\end{array}$ Januari 2021

Subagiyo, R. (2016). Konsep Kebutuhan dalam Islam. (2), 19-31.

Sugiyono. (2017). Metode Penelitian Kuantitatif, Kualitatif, dan $R \& D$. Bandung: Alfabeta 
Mannan, M.A. (1993). Ekonomi Islam Teori dan Praktek Dasar-dasar Ekonomi Islam, Yogyakarta: Dana Bhakti Wakaf.

Nasution, M. I., \& Prayogi, M. A. (2019). The Utilization of Zakah Productive towards Micro-Business Growth and Mustahik Welfare. Jurnal Ekonomi Pembangunan: Kajian Masalah Ekonomi Dan Pembangunan, 20(1), $1-11$.

Niamulloh. (2013). Metode Fundraising Dana Zakat, Infak dan Sedekah pada Badan Amil Zakat Daerah (Bazda) Kabupaten Sukabumi. Vol 2 (1), 78-88.

Rahmat, P. S. (2009, Januari-Juni). Penelitian Kualitatif. Equilibrium, V(9), 1-8. Diakses Januari 2021

Republik Indonesia. (2016). Peraturan BAZNAS No. 2 Tahun 2016 Pembentukan dan Tata Kerja $U P Z$.

Republik Indonesia. (2011). Undang-Undang Republik Indonesia No. 23 Tahun 2011 tentang Pengelolaan Zakat.
Republik Indonesia. (2001). Keputusan Presiden Republik Indonesia tentang Badan Amil Zakat Nasional Presiden

Republik Indonesia. (1999). Undang-Undang Republik Indonesia No. 39 Tahun 1999 Pasal 5 Ayat (3)

Republik Indonesia. (1945). Undang-Undang Republik Indonesia Pasal 34 Ayat (1)

Ridlo, A. (2014). Zakat dalam Perspektif Ekonomi Islam. Jurnal Al-'Adl, VII(1), 119-137.

Rochaida, E. (2016). Dampak Pertumbuhan Penduduk terhadap Pertumbuhan Ekonomi dan Keluarga Sejahtera di Provinsi Kalimantan Timur. Forum Ekonomi, XVIII(1).

Todaro, M. P., \& Smith, S. (2011). Pembangunan Ekonomi (11nd ed.). (A. Maulana, Ed., \& D. B. Putera, Trans.) Jakarta: Erlangga.

Waluyo, J. (2004, Juni). Hubungan Antara Tingkat Kesenjangan Pendapatan dengan Pertumbuhan Ekonomi: Suatu Studi Lintas Negara. Jurnal Ekonomi Pembangunan, IX(1), 1-20. Diakses Januari 22, 2021 